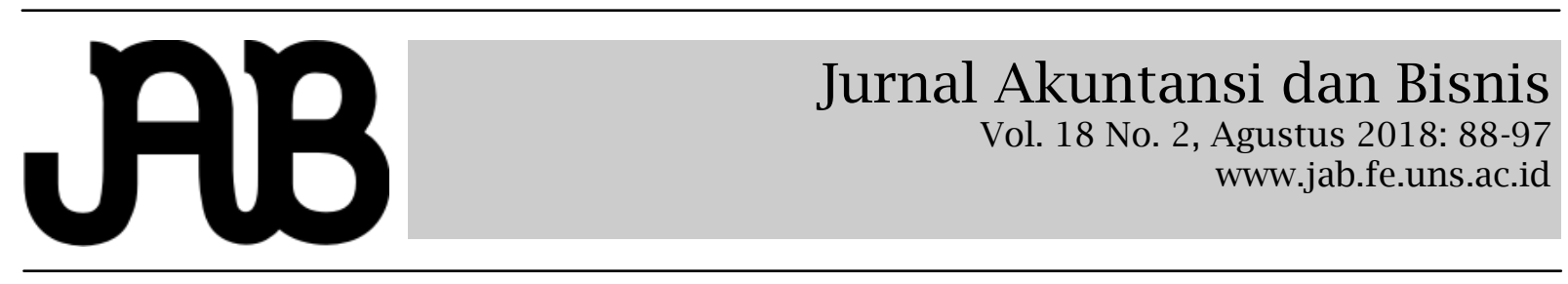

\title{
FACTORS INFLUENCING ACCOUNTING STUDENTS' PERCEPTION OF ACCOUNTING ETHICS: AN EMPIRICAL STUDY IN INDONESIA
}

\author{
MARKO S HERMAWAN ${ }^{1}$ (marko@binus.edu) \\ KOKTHUNARINA² (kokthunarina@yahoo.com)
}

${ }^{1}$ International Business Program, Management Department, BINUS Business School International Undergraduate Program, Indonesia

${ }^{2}$ International Accounting and Finance, Faculty of Economic and Communication, Binus University, Indonesia

\begin{abstract}
A B S T R A C T
This paper proposes a perception of accounting students to overview ethical behaviour during their study in accounting school. The perception is measured by factors pertaining influence to accounting ethics. The variables including perception to cheating misconduct, earning management, environment and culture consideration. A controlling variable of gender and course took are also included in the model. A model of ethical perception is proposed to answer four hypotheses. The sample is accounting students in Bina Nusantara International University. A 5-point Likert Scale is primarily employed in the questionnaire and a multiple Linear Regressions Analysis and Multicollinearity Analysis are used in the model. The research conveys not all variables can influence the accounting ethics. The results are discovered that amongst four variables, there are two variables significantly influence the perception of accounting ethics, which is cheating and environment. The other variables are proven insignificant to student's ethical perception. On the other hand, gender has also no significant to the perception, while course taken variable has strong influence on ethical concern.

Keywords: Accounting, Ethics, Cheating, Earnings Management, Culture
\end{abstract}

Penelitian ini menggambarkan persepsi siswa akuntansi dalam berperilaku etis selama belajar di jurusan akuntansi. Persepsi diukur oleh faktor-faktor yang berhubungan dengan etika akuntansi. Beberapa variabel persepsi adalah tingkat kecurangan, manajemen laba, pertimbangan lingkungan dan budaya. Variabel kontrol adalah jenis kelamin dan mata kuliah juga dimasukkan ke dalam model. Model persepsi etis ini dikonstruksikan untuk menjawab empat hipotesis. Sampel yang diambil adalah mahasiswa akuntansi di Universitas Bina Nusantara. Likert scale dengan skala 5 poin digunakan dalam kuesioner ini dan Analisis Regresi Linier berganda dan Analisis Multikolinieritas dipergunakan dalam model tersebut. Hasil penelitian menyebutkan tidak semua variabel dapat mempengaruhi etika mahasiswa akuntansi. Di antara keempat variabel, ada dua variabel yang secara signifikan mempengaruhi persepsi etika akuntansi, yaitu kecurangan dan lingkungan. Variabel lain terbukti tidak signifikan terhadap persepsi etis siswa. Di sisi lain, jenis kelamin juga tidak signifikan terhadap persepsi tersebut, sementara variabel mata kuliah memiliki pengaruh kuat pada masalah etika.

Kata Kunci: Akuntansi, Etika, Kecurangan, Manajemen Laba, Budaya

\section{INTRODUCTION}

"Ethics in its broader sense deals with human conduct in relation to what is morally good and bad, right and wrong. It is the application of values to decision making. These values include honesty, fairness, responsibility, respect and compassion" Rushworth Kidder, President of Institute for

Global Ethics (Norton, 2009).

Accounting ethics is one of the most important things in the roles of accountant profession. As professional, accountants have a responsibility to embrace a high standard of ethics in terms of providing a fair presentation of information to the public. Thus, it is important to elaborate the relationships between accounting, ethics and accounting ethics.

There are many definitions regarding accounting, ethics and accounting ethics, 
although, the main concepts are generating similar definition. According to Dictionary of Business, accounting is "(a) system that provides quantitative information about the finances of a person or business entity includes recording, measuring, and describing financial information"("Dictioranary of Business term," 2011). Ethics, on the other hand, is defined as a moral principle or values of conduct in a particular class of human, group, organization, culture, etc (Elder, Beasley, \& Arens, 2008). Accounting ethics can be defined as the moral principle or value that accounting use in order to avoid fraud. This supports the notion that accounting ethics is the standard to maintain all financial statement against fraud, misstatement, and other violence.

There several motivations why this paper is important to discuss. Many accounting scandals appeared due to unethical actions from many countries. In particular, private firms have experienced unethical misbehaviour which causes a severe impact to the business environment, such as Enron and WorldCom (Ballantine, Guo, \& Larres, 2016). In Indonesia, several scandals have occurred over the years, such as Century bank, Bali Bank, and Bapindo. The latest scandal in the state tax authority revealed one of the tax officer, namely Gayus Tambunan, has allegedly accused of receiving bribery from his clients (Rangkuti, 2011). Based on these scandals, the public tends to blame accountants as they do not disclose adequate financial reports. The inadequate financial report is derived from the diffusion of information that has not been transmitted completely and properly to the public. Lack of responsibility and ethic may cause the inadequacy of the financial report.

Responsibility and ethics are essential for accountants, in that they need to have ethical behaviour which is important to show good personality. It is vital for public accountants to be ethical since their reputation is at risk. Companies will be reluctant to hire an accountant and company's' reputation will be at risk if accountant does not have a trustable reputation.

More specifically, an important question to rise is whether ethics can be taught in accounting subjects for students and whether or not ethics can be influenced by where students are learning. At the university level, the dishonesty of academic behaviour has been a disturbing action, which enables a bad influence on students (Kassim, Nasir, \& Ahmad, 2015). One possible answers according to International Education practice is that ethics can be taught by practising in the case study, watching the ethical video, demonstrating ethical judgment and decision making skills (Kerr \& Smith, 1995). In addition, there are seven International Education Standards (IES) as a guidance to construct professional accountant. One of them stated in IES 4 which explains the professional values, ethics and attitude should be taught to produce a professional accountant. By studying accounting ethics, the perceptions of students could change. According to the International Education Studies, the behaviour of students in college could be carried to the future (Bakar et al., 2010).

Academic dishonesty has proven to exist in many countries and many nationalities. Song-Turner (2008) investigates sixtyeight postgraduate international students to examine the context of plagiarism in Australia. She found that almost all respondents agree that plagiarism action is misconduct behaviour. Nonetheless, they often do this as a result of pressure to gain good marks and poor mastery of English language. In the case of Indonesia, dishonesty may possibly occur from elementary school to university levels, which prove that Indonesian education is vulnerable to such reprehensible action. For example, Rangkuti (2011) observes cheating behaviour in accounting university students and found most of them conducted cheating in and out the class. Moreover, Pujiatni and Lestari (2010) found that dishonest action such as cheating is derived from the impetus to gain higher score without hard working and less effort. As a result, students are aware of the behaviour and yet to perform the same unethical behaviour. Hence, this paper analyses

This research attempts to analyse students' perception as one of the factors that could influence the perceptions of ac- 
Factors Influencing Accounting Students' Perception of Accounting Ethics: An Empirical Study in Indonesia (Hermawan dan Kokthunarina)

counting ethics. Accounting ethics are bound by factors that influence students' behaviour in and out the class, which commonly presumed as dishonest behaviours. Moreover, the purpose of this research is to gain a deeper understanding of which factors could influence the perceptions of accounting ethics based on student perceptions.

The following explains the sequence of the paper; introduction, literature review, research methodology, findings and discussion, and conclusion.

\section{LITERATURE REVIEW AND HYPOTHESIS DEVELPOMENT}

In general, a field of psychology, education and business are constantly investigating the morality and dishonest acts of students. Most of the studies have found a relationship between these behaviours in class and in the workplace. Rakovski \& Levy (2007) argue that students' behaviour and attitudes in class can be carried out the workplace by observing 1,255 business students. They also argue that these students may evidently reflect future business leaders and that academic dishonesty may carry toward their career. Hutton and Wehle (2006) through the Center for Academic Integrity (CAI) found that 50\% of the student believes dishonest act, such as cheating, is a wrong act, but controversially more than $75 \%$ students in academy did some cheating.

Accounting students have quite a distinctive behaviour in that they must gain ethical behaviour when they learn to account in the classroom. Many believe accounting students are enforced to learn ethics from the first year by competent accounting educators. Blanthorne, Kovar, and Fisher (2007) surveyed accounting faculties' opinions and practices regarding ethics education and found that accounting educators acknowledge the importance of ethics education to favour the profession's needs. In addition, 95\% of the faculties agree that ethics should be taught in the classroom.

There have been numerous studies pertaining ethical behaviour, particularly focusing on student's attitude of the cheat- ing act. Ameen, Guffey, and McMillan (1996) investigated the propensity to cheating by observing student's tolerance to cheating, intention to cheat, student cynicism, student's GPA, environment, punishment and gender in accounting students. The result is that all variable, except gender, proved to be significantly related to the propensity to cheat. Moreover, the authors conclude that $96 \%$ of the accounting students express cheating is a wrong act and $16 \%$ of these students said cheating is a serious problem. Another study by Haswell, Jubb, and Wearing (1999) argue that there is a significant relationship between ethical behaviour and cheating in accounting students. Their study concluded that the risk of detection is one indicator to consider student's behaviour to perform cheating in class. Moreover, the empirical result denotes that $38 \%$ of all students involved in plagiarism if there was zero risk of detection (p. 233). Thus, the study suggests severe punishment is needed to reduce the act of cheating.

There are issues, however, that may not be adequate for studies in Indonesian context due to cultural context. This is because many references presume to have a different context against those in Western countries (Baskerville, 2003; Hermawan, 2015). In this case, cultural context involves closely to student's behaviour to cheat in class. Rangkuti (2011) studies 120 accounting students at Jakarta State University and observes their cheating behaviour during a test in class and doing assignments outside the classroom. The result indicates that cheating occurs on both occasions and that he argues this behaviour may decrease students' honesty in the workplace. Pujiatni \& Lestari (2010) study the behaviour of cheating in 26 students in private university in Surakarta. They reveal three areas of qualitative study, namely student's view of cheating, student's experience in cheating and factors to cheat. Pudjiastuti (2012), on the other hand, studied the cheating behaviour of psychology students and the relationship to selfefficacy. She found that the higher the selfefficacy the lower the cheating behaviours of a student. In sum, students are aware 
that cheating is a serious misconduct, but yet they are conducting the action as a cause of laziness and willingness to achieve a high score in an instance.

From the above studies, the first hypothesis is thus can be developed:

H1: The perception of accounting ethics is influenced by the degree to which student perform cheating in class

In terms of accounting student's awareness of earnings capability, several types of research have been conducted recently. Fischer and Rosenzweig (1995) argue that accounting, as well as operating, manipulation can be considered as an important factor to justify personal preference to ethical conduct. They observe undergraduate students, MBA students, and accounting practitioners and found that undergraduate students view operating manipulation more unethical that those accounting professionals. One of the possible reason is that the professionals often exposed to business in real, in which their ethical idealism become loosen compared to the more idealistic accounting students.

For the case of Indonesia, Anwar and Amarullah (2006) investigate the difference between accounting students' perception and the ethics arrangement of financial statement. They compare between accounting students and non-accounting students after learning accounting course and the indicator used to measure students' perceptions are Misstatement, Disclosure, Cost -Benefit and Responsibility. The study found that accounting students are more prudent to earnings management practices than the non-accounting ones. Thus, the second hypothesis can be developed:

H2: The perception of accounting ethics is influenced by the degree to which students are learning earning management in class

Henry and Dodson (2009) argue that the community and situation have bigger influence in changing the environment's perception. Based on the perception from one of many respondents in the working paper, the family and friends have the biggest influence in learning the ethics and integrity. They argue that "... they learn many things from their parents and their childhood mentors...these role models act ethically, ... the child will learn to do so as well and do so in their future" (p.20). In the accounting field, Ameen et al. (1996) found that accounting students who see others cheat without getting caught enable them to copy the same act. They conclude a positive relationship between student's environment and the propensity to cheat. Therefore, the third hypothesis is as follow: H3: The perception of accounting ethics is influenced by the student's environment

In relation to the cultural context, professional values and ethical development may have differences in interpretation and application. Jeffrey, Weatherholt, and Lo (1996) expressed the importance of the cultural effect, in which these values should be extended to other commitments and social groups and, moreover, Hunt and Vitell (1986) have shown the influence of cultural environment on ethical consideration, which includes religion, legal and political system. Unlike the professional commitments research, cultural impact has similar characteristics to professional and ethical considerations. Cohen, Pant, and Sharp (1996) found relationships between ethical sensitivity and power-distance and Confucian dynamism, while Smith and Hume (2005) found individualism plays a significant role in ethical beliefs. Based on the above studies, the fourth hypothesis can be developed:

H4: The perception cultural context positively affects accounting ethics

Course-related to ethics acquaintance and genders are considered as factors that influence the behaviour of accounting students. Both have been studied by several researchers and found significant relationship with a person's behavioural action. Ismail and Yussof (2016) found that gender factor has a significant impact in cheating behaviour. Haswell et al. (1999) argue that gender has strong influence in student's ethical perception. They found that females tend to be more ethical than male. On the other hand Ameen et al. (1996) and Clikeman, Geiger, and O'Connell (2001) found weak evidence of gender in relation to ethical perspective. In terms of ethics course to 
taken by accounting students, Blanthorne et al. (2007) argue that 95\% of accounting faculties agree to include courses related to ethics, to be taught in accounting classes. Therefore, the two variables, namely gender and ethics courses, are included in the model as controlling variables.

\section{RESEARCH METHODS}

The purpose of this quantitative research is to measure the extent to which accounting ethics is perceived in accounting students. In order to support this, a survey method is used for data collection by employing questionnaire. The questionnaire is distributed to 146 accounting students at Bina Nusantara International University, Jakarta, and they were asked to answer all questions voluntarily. It is imperative to interact directly with these students in order to ensure the questionnaires are given to all students and participate throughout the data collection process.

This research is considered an exploratory study where the major emphasis is to gain ideas and insights (Bennet, 1995). The questioner consists of five parts; consecutively accounting ethics, the perception of cheating, the perception of earning management, the perception of environment and perception of culture. The development of question was based from several measurements by Fischer and Rosenzweig (1995), Anwar and Amarullah (2006), Henry and Dodson (2009), and Jeffrey et al. (1996), which is in accordance to Indonesian context. What is important is the way in which all questions are related to the Indonesian context of cheating and ethics. A 5-point Likert Scale is primarily employed in the questionnaire which involves a respondent's decision to choose his/her stage from strongly disagree (point 1 ) to strongly agree (point 5) (Sekaran, 2003).

The research gives more attention to the perceptions of accounting students, hence the data will be collected from each accounting students from the first until last semester. Table 1 shows the distribution of accounting students as participants. The questionnaires are distributed to all students studying in all semesters. The data is then being processed by SPSS in order to retrieve and analyse the result, which will assist in interpreting hypothesis.

Multilinear regression as defined by Defusco, McLeavey, Pinto, \& Runkle ( 2007) is a tool to observe the relationship among two different types variables, between one dependent and multiple independent variables. In order to answer the hypothesis, multiple regression is used to interrelate accounting ethic perception as the dependent, with the other independent variables shown in the model below:

$$
\begin{aligned}
\mathrm{Yi}= & \alpha+\beta_{1} \mathrm{Ch}+\beta_{2} \mathrm{EM}+\beta_{3} \mathrm{En}+\beta_{4} \mathrm{Cul}+\beta_{5} \mathrm{Cor}+ \\
& \beta_{6} \mathrm{Gen}+\mathrm{e}_{1}
\end{aligned}
$$

Where:

$\mathrm{Yi}=$ the perceptions of accounting ethic

$\mathrm{Ch}=$ Cheating factor

EM = Earning Management Factor

En $=$ Environment Factor

$\mathrm{Cul}=$ Culture Factor

Cor $=$ Dummy variable of course related with accounting ethics $(1=$ taken; $0=$ not taken)

Gen $=$ Dummy variable of Gender $(0=\mathrm{fe}-$ male; 1 = male)

$\epsilon_{\mathrm{i}} \quad=$ the error term

Multi-collinearity occurs when two or more independent variables (or combination of independent variables) are highly (but not perfectly) correlated with each other"(Defusco, McLeavey, Pinto, \& Runkle, 2007).

\section{ANALYSIS AND DISCUSSION}

This research employs several tests that are formulated to assist the provided hypothesis. The questionnaires were distributed to students studying in semester 2, 4, 6 , and 8 , also consider both female and male respondents. There are 94 returned

Table 1.

Distribution of Accounting Students

\begin{tabular}{cc}
\hline \multicolumn{2}{c}{ Accounting Students } \\
\hline Semester & Total \\
2 & 40 \\
4 & 44 \\
6 & 30 \\
8 & 30 \\
10 & 2 \\
Total accounting students & 146 \\
\hline
\end{tabular}


questionnaires or $64.384 \%$ of the total questionnaires distributed. This is due to students who did come to class and students not answering the questionnaire properly. In addition, there are some questionnaires that are lost during the distribution.

Table 2 shows the descriptive statistic of the samples. There are seven variables depicting the subsequent model, namely Accounting ethics, Cheating, Earnings Management, Environment, Culture, Ethics course and Gender. The table represents the mean, minimum, maximum, standard deviation, and multicollinearity analysis for each of the variables. As formulated, accounting ethics act as the dependent variable, with cheating, earnings management, environment and culture as independent variables, while ethics course and gender as the controlling variables.

As described in the table, the mean of accounting ethics is 3.65 which indicate that the respondent's answer is incline to the need of ethics for accounting students. Cheating variable shows a mean of 2.65, indicates that the majority of accounting students have performed cheating in class. In the Earning Management variable, the mean of 2.56 represents the tendency of disagreement to earnings management action, while the environment variable illustrates a mean of 3.82, indicating a tendency to support environment as an important factor to accounting ethics. Culture variable shows that most of the respondent tend to agree that culture is one of the factors influencing ethics, with a mean of 3.45 .

The dummy variable of course taken

Table 2.

Descriptive Statistics

\begin{tabular}{|c|c|c|c|c|c|}
\hline Var. & Mean & Min & $\operatorname{Max}$ & Std & VIF \\
\hline $\begin{array}{l}\text { Accounting } \\
\text { Ethics }\end{array}$ & 3.65 & 1 & 5 & 0.839 & 1.000 \\
\hline Cheating & 2.68 & 1 & 5 & 1.184 & 1.142 \\
\hline $\begin{array}{l}\text { Earnings } \\
\text { Management }\end{array}$ & 2.56 & 1 & 5 & 1.255 & 1.045 \\
\hline Environment & 3.82 & 1 & 5 & 0.687 & 1.031 \\
\hline Culture & 3.45 & 1 & 5 & 0.811 & 1.035 \\
\hline $\begin{array}{l}\text { Ethics } \\
\text { course }\end{array}$ & 0.79 & 0 & 1 & 0.411 & 1.108 \\
\hline Gender & 0.59 & 0 & 1 & 0.495 & 1.096 \\
\hline
\end{tabular}

represents whether or not students have taken courses related to accounting ethics during their study. The selected courses considered to embed ethical acquaintance are accounting theory, auditing, management accounting and accounting information systems. Based on the descriptive statistics, the mean 0.79 illustrates $79 \%$ of the students have taken the ethics embedded courses, with 0.411 standard deviations. On the gender point of view, this research is mostly equal between male and female respondents.

Multi-collinearity is used to determine whether the independent variable related between one another (Priyatno, 2008). One of the requirements to run multiple regression models is to have no multicollinearity in the sample data (VIF > 1). In general, the result shows that all variables have no direct influence amongst each other.

In order to test the model, multiple linear regression is used to determine the relationship between the dependent and the provided independent variables. Table 3 illustrates the result of the model, indicating a strong relationship between perception of ethics and the six factors (pvalue $=0.000$ )

Based on the Defusco, Mcleavey, Pinto \& Runkle (2007), adjusted $\mathrm{R}^{2}$ is defined as a measure of goodness of fit which does not increase when there is additional independent variable. In the model of this research, adjusted $\mathrm{R}^{2}$ is 0.182 , this means that $18.2 \%$ of the dependent variables were explained the independent variables. The result of $\mathrm{R}^{2}$ is 0.235 , that the independent variables can explain $23.5 \%$ of the depend-

Table 3.

Model Summary and Validation

\begin{tabular}{lccc}
\hline \multicolumn{1}{c}{ Variable } & Coef & t-stat & p-value \\
\hline Model & & 1.063 & \\
Acc. Ethics & 0.307 & 3.245 & 0.002 \\
Cheating & 0.021 & 0.100 & 0.921 \\
Earnings Mgt & 0.353 & 3.679 & 0.000 \\
Environment & 0.100 & 1.118 & 0.267 \\
Culture & 0.101 & 0.925 & 0.001 \\
Ethics Course & 0.049 & 0.495 & 0.622 \\
Gender & 0.235 & & \\
R $^{2}$ & 0.182 & & \\
Adj R & 4.411 & & \\
F-stat & 0.001 & & \\
\multicolumn{1}{c}{ p-value } & & & \\
\hline
\end{tabular}


ent variables.

According to the significant value of the model in this research, which is 0.001 , the number represents a strong model to explain that the independent variables can influence the dependent variable. This indicates that all variables have strong influences on the dependent variable.

The variable of cheating has the significant value of 0.002 which means that cheating has strong influencing with the dependent variable which is the perceptions of Accounting Ethics. This result is supported by Ameen et al. (1996), Haswell et al. (1996), Rangkuti (2011) and Pujiatni and Lestari (2010). In can be concluded that this hypothesis is strongly explaining the obvious account that cheating can influence heavily in accounting students' ethical behaviour. In the extent to Indonesian case, the cheating technique varies amongst accounting students, ranging from calculator misuse and mobile phone communication (Rangkuti, 2011). Thus, this misconduct action must be controlled and, more severely, punished by the school's authorities in order to be reduced. This result is also an important note that ethical behaviour may be jeopardised by the fact cheating misconduct can influence the behaviour of accounting students, which in turn can influence their behaviour in the workplace. As Henry and Dodson (2009) stated, once unethical attitudes get interlaced into the community the morale drops and situations such as fraud have a better chance of occurring. The above argument thus supports hypothesis $\mathrm{H}_{1}$.

In terms of Earning Management variable, this factor has a weak influence towards ethical behaviour, with a significant value of 0.921 . As it is higher than 0.05 , the variable does not have strong influence on perceptions accounting ethics. This result contradicts Fischer and Rosenzweig (1995) and Anwar and Amarullah (2006). Their arguments that earning management is an important factor in determining accounting ethics seem not be proven in Binus International accounting students. A possible reason is that these students may aware of the earnings manipulation but fail to interrelate in the extent of accounting ethical be- haviour. Other reason may occur because most of the accounting students do not fully understand that earnings manipulation may affect their behaviour. This result thus does not support hypothesis $\mathrm{H}_{2}$ and is rejected.

The environment variable in the model has a strong influence in determining accounting ethical behaviour to the student, with a significant value of 0.000 . The finding is supported by Ameen et al. (1996) and Henry and Dodson (2009). It is evident that student's environment has an influential effect on their behaviour, particularly family and friends. As Ameen et al. (1996) argue, a student may copy what his or her friend is acting, including cheating misconduct, so he or she may replicate the same action as a result of the environmental situation. What matters is that school or university must take serious action in order to develop a condition whereby cheating or other misconduct behaviours may not occur in these environments. In addition, Henry and Dodson (2009) describe the importance of family and friends that ethics and integrity can be learned in conjunction with school impacts. The above explanation supports this hypothesis and thus hypothesis $\mathrm{H}_{3}$ is accepted.

In the culture variable, the result shows a weak influence on the perception of ethical behaviour, with a significant value of 0.267 . This contradicts the previous findings by Jeffrey et al. (1996), Cohen et al. (1996) and Smith and Hume (2005). One possible reason is that culture consideration may presume different in the Indonesian context. Moreover, there is an indication that the previous measurement of cultural context may have altered alongside the dynamism of country's influence to globalisation. Moreover, (Ailon, 2008) argued that there has been a western bias in the development of cultural questionnaires and questioned whether the findings capture such racial and colonial inequalities. Indonesian cultural context, in addition, may have different characteristics than the western point of view, which can alter the perception of accounting students. The above explanation concludes that hypothesis $\mathrm{H} 4$ is rejected. 
As controlling variables both ethics courses taken and gender have different result based on the provided model. The ethics course variable shows a strong influence on accounting ethics with a significant value of 0.001 ( $\mathrm{p}$-value 0.005 ), while gender variable shows a weak influence of 0.622 . This result indicates that ethics course taken by students indicate influence to the perception of ethics to accounting students, as supported by Kerr and Smith (1995). On the other hand, gender seems to be a weak control variable to the perception of accounting ethics, which is supported by Clikeman et al. (2001).

The presented model shows the factors that influence the perception of accounting ethics in accounting students. Cheating is the most obvious factors to determine whether or not students act wisely. Cheating, including plagiarism, has been a major problem throughout the education system in that students are aware of this behaviour, but tend to perform it. There have been several cases found in university in Indonesia, where accounting students are willing to cheat during and outside the classroom. More importantly, this paper contributes to the fact that gender factor has no influence on cheating intention. This means either male or female has a propensity for performing unbehavioural ethics. It is believed that Indonesian, with a multi-religion context has little influence with the manifestation to prevent cheating behaviour. Indonesian values and norms may also contribute to the development of ethical behaviours. However, the finding shows otherwise. Punishment, as one of the deterrent effects, is proven to be an effective controlling mechanism in an educational environment. Universities are enforced to give severe punishment to students who caught cheating in and outside the class in order to uphold ethical behaviour when they are to be an accountant. The perception to gain high standard in ethical behaviour is an important aspect to become a qualified accountant, as accounting students must equip themselves with fair objectivity and integrity.

\section{CONCLUSION}

The aim of this research is to investigate factors that can influence the perceptions of accounting ethics. The purpose is to observe to what extent these factors can contribute significantly to accounting ethics in education account. These perceptions of accounting ethics are meant to help the future research to identify more factors that can clarify that factors which can influence the students' perceptions.

As mentioned before, the students' perceptions of accounting ethics are important because it could influence their future attitudes and behaviour in the workplace. As explained in the discussion, there is a significant connection between behaviour, attitudes, intentions and perceptions. In this study, the strongest factors used to determine ethics perception are cheating, environment, and ethics course factors. Cheating and environment are considered as acceptable factors in that they understand the importance of academic integrity and fully aware of the university, as well as family, an environment where ethics can be nurtured.

\section{LIMITATTION AND SUGGESTION}

One obvious limitation is that as the adjusted $\mathrm{R}^{2}$ is only $18.2 \%$, other undetected factors, may offer more explanatory reasoning to dishonest behaviour. Several recommendations are listed in order to improve further research in accounting ethics.it is recommended to extend the relationship between cheating and accounting ethics which will clarify the relationship between the academic integrity and ethics in accounting. The samples in the future research should be more than one sample. By more samples, there will be more consideration of the perceptions of accounting ethics and the results will be more accurate. In the next research should be more reflecting the relationship between the behaviour of students and the perceptions which it could be influencing the perceptions of accounting ethics. The perceptions of academic dishonesty and accounting ethics should be more observed in order to observe the relationship between them.

\section{REFERENCE}

Ailon, G. (2008). Mirror, Mirror on the Wall: Culture's Consequences in a Value 
Factors Influencing Accounting Students' Perception of Accounting Ethics: An Empirical Study in Indonesia (Hermawan dan Kokthunarina)

Test of its Own Design. Academy of management review, 33(4), 885-904.

Ameen, E. C., Guffey, D. M., \& McMillan, J. J. (1996). Accounting students' perceptions of questionable academic practices and factors affecting their propensity to cheat. Accounting Education, 5(3), 191-205.

Anwar, Y., \& Amarullah, F. (2006). Perbedaan Persepsi Mahasiswa Akuntansi Terhadap Etika Penyusunan Laporan Keuangan. Jurnal Akuntansi dan Keuangan Indonesia, 3(1), 107 - 126.

Bakar, K. A., Tarmizi, R. A., Mahyuddin, R., Elias, H., Luan, W. S., \& Ayub, A. F. M. (2010). Relationships between university students' achievement motivation, attitude and academic performance in Malaysia. Procedia-Social and Behavioral Sciences, 2(2), 49064910.

Ballantine, J. A., Guo, X., \& Larres, P. (2016). Can Future Managers and Business Executives be Influenced to Behave more Ethically in the Workplace? The Impact of Approaches to Learning on Business Students' Cheating Behavior. Journal of Business Ethics, 1-14.

Baskerville, R. F. (2003). Hofstede never studied culture. Accounting, Organizations and Society, 28(1), 1-14.

Bennet, P. D. (1995). Dictionary of Marketing Terms, second ed. Chicago: Lincolnwood.

Blanthorne, C., Kovar, S. E., \& Fisher, D. G. (2007). Accounting educators' opinions about ethics in the curriculum: An extensive view. Issues in Accounting Education, 22(3), 355-390.

Clikeman, P. M., Geiger, M. A., \& O'Connell, B. T. (2001). Student perceptions of earnings management: the effects of national origin and gender. Teaching Business Ethics, 5(4), 389-410.

Cohen, J. R., Pant, L. W., \& Sharp, D. J. (1996). A methodological note on cross-cultural accounting ethics research. The International Journal of Accounting, 31(1), 55-66.

Defusco, R. A., McLeavey, D. W., Pinto, J. E., \& Runkle, D. E. (2007). Quantitative Investment Analysis. Hoboken: John WIley \& Sons, Inc.
Dictionary of Business term. (2011). Retrieved from http:// www.allbusiness.com/glossaries/ accounting/4943017-1.html

Elder, R. J., Beasley, M. S., \& Arens, A. A. (2008). Auditing and Assurance Services. New Jearsey: Pearson Education,Inc.

Fischer, M., \& Rosenzweig, K. (1995). Attitudes of students and accounting practitioners concerning the ethical acceptability of earnings management. Journal of Business Ethics, 14 (6), 433-444.

Haswell, S., Jubb, P., \& Wearing, B. (1999). Accounting students and cheating: A comparative study for Australia, South Africa and the UK. Teaching Business Ethics, 3(3), 211-239.

Henry, K., \& Dodson, B. (2009). Ethical Education and its Effect on Accounting Fraud. Working Paper. Christopher Newport University.

Hermawan, M. (2015). An investigation of organisational culture: a case study of Indonesia's professional accounting firms. (PhD), Victoria University of Wellington, New Zealand.

Hunt, S. D., \& Vitell, S. (1986). A general theory of marketing ethics. Journal of macromarketing, 6(1), 5-16.

Hutton, P. A., \& Wehle, R. J. (2006). Understanding Students Cheating and What educators Can Do About it. Retrieved from

Ismail, S., \& Yussof, S. H. (2016). Cheating behaviour among accounting students: some Malaysian evidence. Accounting Research Journal, 29(1), 2033.

Jeffrey, C., Weatherholt, N., \& Lo, S. (1996). Ethical development, professional commitment and rule observance attitudes: A study of auditors in Taiwan. The International Journal of Accounting, 31(3), 365-379.

Kassim, C. K. H. C. K., Nasir, N. E. M., \& Ahmad, S. (2015). Academic Dishonesty of Accounting Students at Higher Learning Institutions. Mediterranean Journal of Social Sciences, 6(4), 702.

Kerr, D. S., \& Smith, L. M. (1995). Importance of and approaches to incor- 
porating ethics into the accounting classroom. Journal of Business Ethics, 14(12), 987-995.

Norton, K. (Producer). (2009, September 28). ArticlesBase. Retrieved from http://www.articlesbase.com/ethicsarticles/ethics-in-accounting1276428.html

Priyatno, D. (2008). Mandiri Belajar SPSS (Statistical Product and Service Solution). Jakarta: MediaKom.

Pudjiastuti, E. (2012). Hubungan "Self Efficacy" dengan Perilaku Mencontek Mahasiswa Psikologi. MIMBAR, Jurnal Sosial dan Pembangunan, 28(1), 103111.

Pujiatni, K., \& Lestari, L. (2010). Studi Kualitatif Pengalaman Menyontek pada Mahasiswa. Jurnal Penelitian Humaniora, 11(2), 103-110.

Rakovski, C. C., \& Levy, E. S. (2007). Academic dishonesty: Perceptions of business students. College Student Journal, 41(2).

Rangkuti, A. A. (2011). Academic cheating behaviour of accounting students: A case study in Jakarta State University. Paper presented at the 5th Asia Pacific Conference on Educational Integrity, The University of Western Australia.

Sekaran, U. (2003). Research Methods for Business: A Skill Building Approach: John Wiley and Sons.

Smith, A., \& Hume, E. C. (2005). Linking culture and ethics: A comparison of accountants' ethical belief systems in the individualism/collectivism and power distance contexts. Journal of Business Ethics, 62(3), 209-220.

Song-Turner, H. (2008). Plagiarism: Academic dishonesty or blind spot of multicultural education. Australian Universities Review, 50(2), 39-50. 